\title{
Semiotic dimensions of human attitudes towards other animals: A case of zoological gardens
}

\author{
Nelly Mäekivi, Timo Maran \\ Department of Semiotics \\ University of Tartu \\ Jakobi 2, Tartu, 51014, Estonia \\ e-mail: nelly.maekivi@ut.ee; timo.maran@ut.ee
}

\begin{abstract}
This paper analyses the cultural and biosemiotic bases of human attitudes towards other species. A critical stance is taken towards species neutrality and it is shown that human attitudes towards different animal species differ depending on the psychological dispositions of the people, biosemiotic conditions (e.g. umwelt stuctures), cultural connotations and symbolic meanings. In real-life environments, such as zoological gardens, both biosemiotic and cultural aspects influence which animals are chosen for display, as well as the various ways in which they are displayed and interpreted. These semiotic dispositions are further used as motifs in staging, personifying or de-personifying animals in order to modify visitors' perceptions and attitudes. As a case study, the contrasting interpretations of culling a giraffe at the Copenhagen zoo are discussed. The communicative encounters and shifting perceptions are mapped on the scales of welfaristic, conservational, dominionistic, and utilitarian approaches. The methodological approach described in this article integrates static and dynamical views by proposing to analyse the semiotic potential of animals and the dynamics of communicative interactions in combination.
\end{abstract}

Keywords: zoosemiotics; zoological gardens; animal evaluation; charismatic species; personification

\section{Introduction}

The aim of the present paper is to map the semiotic aspects of human evaluation of nonhuman animals. The question of human attitudes towards nonhuman animals is predominantly tackled by in environmental psychology, animal welfare studies etc., but it also falls in the realm of semiotic study, as it is connected with cultural codes and practices, symbols and connotative meanings. In this paper, we focus on the relationship of different cultural layers of human attitudes towards other animal species and juxtapose these with the specific characteristics of nonhuman animals 
themselves. Inasmuch as human attitudes towards nonhuman animals depend on the properties and communication capacities of animal species, they also constitute a topic of biosemiotic and zoosemiotic concern. As a practical application, we analyse the complexities of human attitudes towards animal species in zoological gardens and review the different strategies that are used there to modify human-animal relations. After that we elaborate the existing zoosemiotic typologies of anthropocentric attitudes and evaluation of animals and present a compound model to analyse different and conflicting positions of animals in zoological gardens.

Although studies have demonstrated profound differences in how various human groups evaluate different nonhuman animal species, this issue has remained overlooked in many practical areas that deal with nonhuman animals in the framework of legal regulation and moral judgments. It can be argued that when the humanities and social sciences attend to other animals, their research is influenced by different cultural perceptions and moralistic attitudes. It is also widely accepted that when laity or "common people" deal with animal-related topics, their attitudes are mostly humanistic (Koontz 1995: 131). A similar stance is not often recognized in natural sciences that can be argued to hold scientific, ecological or other ethically unburdened attitudes toward animals. When dealing with practical issues concerning animal management, biodiversity, species conservation, etc., it is evident that decisions stemming from cultural perceptions pertaining to the species in question are restrained or rationalized with scientific explanations, thus minimizing or eliminating the distinctions that arise from an emotional affinity with certain species. This neutrality is a proclaimed position of many institutions working with animals, but the fabric of species egalitarianism often hides different factors of preference. ${ }^{1}$ In a milder version, the differences in attitudes are assumed to be rational, based on objective properties and differences in the species themselves. Let us consider two hypothetical examples: first, the list of species that, in legal documents, are considered to be invasive in a given fauna and are considered to be subjects of removal from the local ecosystem. Second, let us consider a situation in which zoological gardens make a decision for which nonhuman animals need to be removed as surplus individuals from a given ex situ population. In both cases, the moral assumption seems to be that such decisions have a rational basis and that they are based on an awareness of biological knowledge, while apart from that, the species and individuals are treated in an equal way. In other words, it is assumed that in many areas of human-animal relations, there should be no place for preferences deriving from cultural background, human evolutionary experience or personal histories.

1 This understanding takes into account (but is not directly based on) our earlier research on visitor studies in Tallinn Zoological Gardens conducted by Mäekivi in 2010 and 2012 and on the discourse of the golden jackal (Canis aureus) as an alien species in Estonia (Maran 2015). 
The main argument of this paper is that there are deep culturally and biologically driven causes for humans' varying attitudes towards specific species. In actual species conservation and animal welfare cases these attitudes may form a complex pattern of interactions between different interest groups, and therefore also need special attention in the semiotic study of human-animal relations. As an example of this necessity, in the final part of the paper we present an analysis of the contrasting interpretations of culling a giraffe at the Copenhagen zoo.

The dynamics of human attitudes towards other animals is predominantly addressed in environmental psychology. The majority of studies have related the approach to nonhuman animals to underlying human psychological dispositions, often in relation with general environmental values of humans. In a well-known typology, Stephen Kellert distinguished general values that humans associate with wildlife: naturalistic/outdoor recreational value, ecological value, moral or existence value, scientific value, aesthetic value, utilitarian value, and cultural/symbolic/ historical value (Kellert 1988: 52-53). In regard to nonhuman animals, Adelma M. Hills (1993: 111) has proposed three "motivational bases, where responses to animals depend on instrumental self-interest, empathy identification, or people's beliefs and values about the nature and status of animals". In general, several dominants can be distinguished in the studies on human attitudes towards nonhuman animals: (1) differences in regard to different animal species; (2) typologies of human attitudes; (3) different aspects or layers in valuation; (4) differences in valuation in regard to different social groups, genders, cultures, and others. Although not yet thoroughly developed, the realization of the importance of human attitudes towards other species is also starting to evolve in practical aspects of animal management - as William Conway (2003: 11) puts it: "Fundamentally, the saving of wildlife is a social process [...]. Ultimately, it depends less upon 'how' than upon 'why'?. The existence and charisma of living animals are the best answers".

Concerning the different attitudes in regard to different animal species, Stephen Kellert contributed pioneering studies in the late 1970s about public support towards nature conservation programmes (Kellert 1985, 1988). His inquiry that included eight local species showed that people's readiness to support the protection of different species groups differs considerably across species [protection efforts of the bald eagle were supported by $89 \%$, the eastern mountain lion by $73 \%$, the Agassiz trout by $71 \%$, the American crocodile by $70 \%$, the silverspot butterfly by $64 \%$, the eastern indigo snake by $43 \%$ and the Kauai wolf spider by $34 \%$ of responders (Kellert 1988 : 57)]. Later, similar results regarding differential attitudes toward various animal species have been gathered in various geographical areas and contexts: in ecotourism (Woods 2000), urban environment (Bjerke, Østdahl 2004), zoological gardens (Myers, Saunders 2004), and educational institutions (Schlegel, Rupf 2010). For 
attitudes towards nonhuman animals, the similarity of the animal species to humans seems to be a decisive factor (Batt 2009), albeit not the only factor. The relationships between different aspects in human valuation of nonhuman animals have been brought together, for instance, by J. A. Serpell (2004) under the concept of 'attitude modifiers', which differentiates individual human attributes, animal attributes and cultural factors (including the effects of science). ${ }^{2}$ Semiotic aspects of human valuation of nonhuman animals have been addressed by several authors paying predominant attention to the underlying semiotic mechanisms: semiosis, umwelt, intentionality (Kull 2001; Martinelli 2008; Beever 2012; Pahin, Macfadyen 2013). Dario Martinelli (2007: 177-178, 2008) presents a two-dimensional and relatively static model for classifying anthropocentric attitudes that distinguishes between scientific/pragmatic, spiritual/emotional, and zoophilic and zoophobic attitudes.

The question of human attitudes to nonhuman animals appears to be multidimensional and relatively dynamic. In the following sections, we focus on the semiotic aspects, that is, on cultural reasons for evaluating nonhuman animals and on characteristics specific to different animal species, from many possible angles. In doing this, our goal is to demonstrate that existing psychological and sociological understandings of animal valuation would benefit from considering cultural semiotic and biosemiotic aspects to a greater extent.

\section{How culture models nonhuman animals}

Different definitions of 'animal' tend to be twofold: firstly, they stress the scientific denotative aspect of the animal as a multicellular being belonging to the animal kingdom; and secondly, they draw our attention to connotative meanings in making semantic distinctions. Especially prevalent are cases where the word 'animal' refers to a whole from which humans are excluded. As part of a connotative dimension, cultural-mythological meanings of different animal species have deep ramifications in history, art and religion with many forms and faces in contemporary culture. Characteristics attributed to animal species, such as lions and eagles referring to royalty, collective Hymenoptera referring to diligence and discipline, swans and doves referring to virtue and faithfulness, wolves, jackals and other Canidae referring to rudeness and traitorousness, owls referring to wisdom and mystery and so on constitute a rich and complex fabric of cultural imagination. Cultural-mythological motifs may form themes that are centred around some features or properties and

2 In addition, human attitudes toward animal species can be influenced by occasional factors, such as environmental or temporal context or personal history and experience with the specific animal species. 
that, in this way, surpass the limits of the taxonomical system. The connecting logic is often analogical and imitative (corresponding to J. G. Frazer's principle of sympathetic magic). For example, in the context of Estonian culture, dark plumage is a connecting feature for birds of omen that are taxonomically far from one another: the raven Corvus corax, the black stork Ciconia nigra, the black woodpecker Dryocopus martius (Mäger 1994).

In contemporary Western culture, mythological motifs are weakening, although they probably form an important layer of connotative meanings in animal appreciation (for a discussion on 'cultural keystone species', see Garibaldi, Turner 2004). Today the mythological meaning layer appears to be outweighed by a scientific understanding and valuation, although in public discourse they can also become combined. 'Scientific value' has been distinguished as one of the general values or benefits that people use to associate nature and nonhuman animals with (Kellert 1988: 53). At the same time, science is an institution and discourse with a specific history and practices that influence the ways in which specific species and groups have been appreciated. What is particularly noticeable here is the legacy of 18th- and 19th-century natural history and the effect of species collections on attitudes toward nonhuman animals. Taxonomical groups that have been historically treated as "collectibles" - higher plants, birds, small fish, butterflies, Coleoptera - appear to have a more positive reputation compared to the species that have not been objects of natural history collections. ${ }^{4}$ Birds form an especially interesting case: historically objects of taxidermy and oological collections, birds continue to be favourite objects of attention for today's amateur naturalists (cf. Moss 2004). The connecting feature of different practices is the valuation of the number of species collected or recorded with a special emphasis on rarity. Such cultural practices may be assumed to create a general positive background for attitudes towards finding a rare or alien species in a given area. For this reason, new bird species are often welcomed in public media with an interested and curious attitude, whereas attitudes towards carnivorous mammals are much more cautious and negative.

Both the cultural-mythological meanings and scientific understandings may consolidate to form well-defined semiotic structures known as symbols. In cultural-mythological modelling, this may take the form of totemic animals, animals used in heraldry, national animals, and others. Scientific understandings tend to symbolize animals that

3 E.g. the U.S. Fish and Wildlife Service issued a permit allowing a Native American tribe in Wyoming to kill two bald eagles for religious purposes, despite the fact that bald eagles are protected under the federal Bald and Golden Eagle Protection Act (Fox News 2012. Wyoming Native American tribe gets rare permit to kill bald eagles. Fox News Politics 14.03.2012. Available at: http://www.foxnews.com/politics/2012/03/14/wyoming-native-american-tribegets-rare-permit-to-kill-bald-eagles/; retrieved on 22.02.15).

4 Among collected groups, there also exists a hierarchy of value based on animal rarity, body size, origin, etc. 
are used and valued as model objects of scientific research in molecular biology, ecology and cognitive studies: Drosophila melanogaster, the nematode Caenorhabditis elegans, the zebra finch Taeniopygia guttata, rhesus monkey Macaca mulatta, and others. In conservation biology and nature protection movements, a special status is often given to the characteristic and charismatic species from a given area as a 'flagship species': the great panda, the Bengal tiger, the kiwi, the European bison, and others. We consider, however, these apparent cases of animal symbolization in cultural-mythological and scientific consciousness to be just peaks in the much more general semiotic landscape that influences interpretations of each and every animal species.

\section{Nonhuman animals as communication partners: appearance and umwelt}

Biosemiotics and zoosemiotics have long argued for the role of animal subjectivity in ecological and evolutionary processes (Hoffmeyer 2008; Markoš et al. 2009; Maran et al. 2011). Following this tradition, we claim that in addition to cultural-mythological and scientific meaning complexes, also the activity of nonhuman animals themselves, their appearance, umwelt and specific properties have an effect on how humans evaluate other animals. At this point, let us distinguish between two principal aspects of appearance and umwelt structure. 'Appearance' (also 'phenomenal structures'; Portmann 1964: 74) was a concept used by German biological philosopher Adolf Portmann (1990: 25-29) to describe the forms and visual patterns of animals that they use to present themselves to the environment. As a means for presentation, animal appearances set out possibilities to establish relationships. These appearances are, however, not fixed to function in existing inter- and intraspecific communicative relations but have also semiotic potential to start new interpretations and new relations: "The surfaces display is a part of the presentation of self of a living being. To be sure, the perceiving eye plays no role in the life-realm in which patterns and designs first arise [...] but, in that same life-realm the possibility of perceived beings already exists and that potential leads to the further promise of an enrichment of living relationships" (Portmann 1990: 25). This property of animal appearances makes emerging new communicative relations possible, including those with humans in the context of natural history collections, pet stores, zoological gardens, etc. Portmann's concept of appearance predominantly refers to animals' exterior surfaces and visual perception, but it can also be used to describe other sensory modalities as well as dynamics of forms and movement. There are evolutionary and ecological causes in many species groups for instance tropical songbirds, butterflies, lizards, and coral reef and freshwater fish to have a vivid appearance. Vivid appearances as well as using them dynamically in 
behavioural displays also provide a good basis for humans to attribute meanings to nonhuman animals and to become emotionally attached to them.

The extent to which humans perceive and interpret other animals' appearances depends on the relationship of their subjective worlds or umwelts (Uexküll 1982). Communication channels and modalities of different animal species differ: in some cases there is a significant overlap between the umwelts of humans and a nonhuman animal species, while in other cases the richness of animal forms and signals is barely accessible to humans (e.g. forms, behavioural and chemical signals of insects). Also, nonhuman animals' capacities and motivation to relate to humans and to address humans by communicative means differ depending on their cognitive capacities, the position of meaning of humans in animal umwelts and other properties. Heini Hediger (1969: 77) has distinguished between five classes of meanings that animals can attribute to humans: an enemy, prey, a symbiont, a piece of inanimate environment or a member of its own species. It appears that physical resemblance, similarity of the sense organs and inhabiting the same environment create the preconditions, but it is rather the correspondence between umwelt structures that directs humans to appreciate some nonhuman animals more than others.

To emphasize the appeal of certain animal groups to humans, specific notions have been proposed such as 'vertebrate chauvinism' (Randall 1986: 88) or 'charismatic megafauna' (Rolston 1990). There are, however, more specific properties that can be considered when making predictions about possible human attitudes towards the given animal species. Classical ethologist Konrad Lorenz proposed the concept of Kindchenschema (cuteness) to denote the specific child-like facial proportions of a flat face with large eyes, small nostrum or nose, etc. that characterize juvenile individuals in many vertebrate groups and also tend to evoke parental caring behaviour (Lorenz 1943). Kindchenschema properties are both individual, but also characteristic of specific species. In zoological gardens and other environments of human-animal encounters, the complex interplay between individuality and speciesspecificity takes place. For Kindchenschema to be enacted and communicative interactions and emotional attachment to develop, concrete individuals are needed. Those animals, however, have a double representational character. They simultaneously represent themselves as individual living beings in their own right and stand for their species as a general type. In the next section, the dynamics and problems of this double representation are described in detail.

In a broader sense, the issue of Kindchenschema or cuteness also evokes the question of possible interactions between humans and nonhuman animals as regards both behavioural (care giving, parental relation) and ecological (symbiosis, predation) relations. This relates to Konrad Lorenz' idea of companion species that was inspired by Jakob v. Uexküll's notion of Kumpan (Lorenz 1937: 260) - that is, a 
species with properties that respond and fulfill the animal's (or human's) behavioural function that is active at the given moment. Relations that make us become attached to some species more than others are thus at least partly pre-cultural and belong to the biosemiotic realm. In zoological gardens, the popularity of different species of zoo animals is measured by visitor interest expressed by the attracting power of the animal(s) (the number of times visitors stop) and holding time of the animal(s) (for how long the visitors stop). The most critical indicator of visitor interests tends to be taxonomic groups, with mammals - belonging to the same class as humans - being the most captivating (Moss, Esson 2010).

As most of the properties mentioned above are permanent for the given species and objectively describable, we propose that it is possible to map the potential of different species to become objects of positive or negative valuation by humans. In such an analysis, the following criteria could be used:

- Is the given species a vertebrate?

- Is its body size comparable to or larger than the human one?

- Does the given species have a collective lifestyle?

- Does the given species have colourful patterns, does it emit loud and diverse sounds, or does it have other rich intraspecific communication strategies accessible to humans?

- Does the umwelt (i.e. the communication channels used, meaning relations to environmental resources) of the given species have considerable overlap with the human umwelt?

- Does the given species have ecological relations (prey-predator relations, symbiosis, parasitism) with humans or is there potential for behavioural (care giving, parental relation) relations?

- Does the Lorenzian concept of Kindchenschema apply for the given species?

If most of these questions receive a positive answer, then the relationship of the given animal species to humans may be seen to enhance human attitudes towards the animal. The question of whether humans value the animal positively or negatively is not addressed here, as this needs more detailed analysis, and also, different interest groups may value the same species differently within the same complex relation. We will return briefly to given points in our case study. What can be deduced generally is just an overall inclination towards valuation. Our argument also questions the imperative of species egalitarianism common in human-animal studies and animal rights philosophy. Even if species egalitarianism is desirable as a principle, our actual relations to other species are often rooted in our cultural and biological history. Difference in valuation comes by default. This means that in areas of human-animal relations where equality of or a neutral attitude towards different species is an important principle, the inclinations and preconceptions involved in valuation need continuous attention and analysis. 


\section{The case of zoological gardens}

Zoological gardens as institutions are particularly suitable examples of how culture and animal characteristics model the perception and lives of non-human animals: here, ample possibilities for inter-species communication arise, which in turn contribute to developing perceptions and attitudes towards different species and individuals inhabiting the zoo environment. This topic is important in order to draw attention to the fact that species-neutrality hardly exists, that human perception of non-human animals is value-laden. The suggestion is that it is problematic to make a clear-cut division between what an animal or a species is (in a biological, ecological, etc. sense) and what people or different interest groups perceive the animal or species to be. More often, especially in practical endeavours, it is very difficult to clearly distinguish between approaches to animals as biological beings and as culturally constructed beings due to the mutual interconnectedness of these approaches.

In addition to a species-biased approach that proves to be quite prevalent in zoo environments, the dynamic nature of perceiving and valuing other species should be analysed in order to comprehend the myriad of possibilities for attitudes and their manifestations in a variety of contexts. Perceptions and attitudes towards non-human animals, although strongly tied to our cultural and biological heritage, are not entirely carved in stone. There are possibilities to facilitate the changing of those perceptions and attitudes or, if need be, creating them in the first place. In modelling people's perceptions or interpretations of other species, the dynamical dimension in altering and influencing attitudes and perceptions has often been left unnoticed or unaccounted for. However, in order to analyse specific case studies dealing with practical aspects in animal management, which, as we claim, often have hidden roots in the basis of how people evaluate animals and species, it is highly relevant to also draw attention to the underlying principles that enable people and different interest groups to shift between different representations and perceptions of a given species or an animal. Consequently, it becomes obvious that human-nonhuman communication - our perceptions, representations, attitudes, etc. of them - and possible alterations of the latter, are closely intertwined.

It is to be argued that with the advent of species conservation, animal rights movements, legislations in animal welfare, etc., the perceptions of zoo animals in general and all the species under scrutiny have never been and are still not uniform. Although the changed functions of zoological gardens ${ }^{5}$ indicate that the

\footnotetext{
5 The zoological gardens have shifted their focus from leisure time entertainment to more serious and profound goals of nature education, scientific work and species conservation. The contemporary zoological gardens of the 21st century consider themselves to be ex situ preservation centres, where Earth's fauna is exhibited in an educational manner (Association of Zoos and Aqariums 2015. Guide to Accreditation of Zoological Parks and Aquariums, 10. Available at: http://www.aza.org/ uploadedFiles/Accreditation/Guide\%20to\%20Accreditation.pdf; retrieved on 05.01.2015)).
} 
zoo institution's understanding of animals in its care has changed, there is a vast diversity in attitudes that visitors and other interest groups hold towards animals in general and towards different species exhibited in zoos. The practical applications of ex situ animal management in zoos (e.g. enclosure enrichment, culling, creating suitable social groupings, sterilizing, etc.) are supported by scientific knowledge of zoo husbandry. Nevertheless, despite the progress of scientific knowledge, animal management practices in zoological gardens can still develop into a major source for inter-group controversies and also, to a certain extent, hinder the survival of some species. Thus the reasons that give rise to differences in opinion pertaining to animal management practices should be reckoned with. We believe that one of the main reasons for these controversies are the underlying various attitudes to and perceptions of animals that people and interest groups have. A semiotic basis for evaluating non-human animals in the context of zoological gardens can shed light on this complex and difficult issue.

Zoosemiotic studies, especially as developed by Dario Martinelli (cf. Martinelli 2007, 2010), permits us to reveal the interconnectedness and strong co-dependence of biological and cultural factors when dealing with human-animal communication, including that occurring in the zoological garden. Non-human animal communication and human non-verbal communication have been described as part of traditional ethological zoosemiotics, while human representations and perceptions of other species form the anthropological branch of zoosemiotics (Martinelli 2010). However, the key factor here is acknowledging that both of the subdivisions are brought together under the common denominator of zoosemiotics, which indicates that they share some generic ground and a starting point in researching communication and representation of other animals. Thus, it is accepted in zoo/biosemiotics, that our cultural tendencies in dealing with other species are strongly rooted in our biological makeup and in our ability to communicate with other species to a lesser or greater extent. As already explained in the introduction of this article, umwelt compatibility of different species plays a crucial role in inter-species communication between humans and non-humans. Since umwelts of different species are not entirely compatible, there is plenty of room for interpretive freedom (including misinterpreting ${ }^{6}$ ) the communicative signals of an

6 Most typical cases that provide evidence for the aforementioned overlap in human and large mammals' umwelts are instances where zoo visitors or other interest groups attribute to mammals the emotions of sadness, boredom, etc., so often exhibited and recognized by people themselves. This is not to claim that other species do not have or do not exhibit emotions, the claim is rather that there is a wide variety of bodily and facial expressions that people are able to recognize in other mammals, but that can still be misinterpreted, e.g. the upturned mouth of a bottle-nose dolphin has made them popular for their friendly smile, although they are actually not smiling; the big cats tend to sleep most of the day, so people often interpret their behaviour as expressing boredom, etc. 
animal from another species. In reality it is very difficult, if not impossible, to clearly distinguish between biological and cultural meanings when analysing concrete cases of animal management, since they are closely intertwined. Thus it remains debatable whether the emphasis on over-representing mammals in human-animal relation studies and in zoological gardens should be put down to our own biological or cultural nature. We believe that accounting for both factors can make it easier to approach problems that arise in human-nonhuman encounters in zoos.

\section{Staging of animals and changing attitudes}

Large charismatic mammals have always been the most popular animals throughout the history of zoological gardens - animals to whom we can best relate and animals that resemble us most, as well as the animals with whom we can best communicate. Animals with the highest 'exhibition value' have forward pointing eyes, because people generally interpret them as more responsive than non-aggressive herbivorous species with laterally placed eyes; however, forward pointing eyes are meant to give accurate depth perception for better pouncing on the prey (Lacy 1995: 191). Although this might indicate a distinction between carnivorous and herbivorous mammals, it does not seem to be severe when we look at the attention given to large mammals in comparison with fish, reptiles, amphibians or even birds. ${ }^{8}$ The claim for popularity of mammals sides with considerable umwelt compatibility between other large mammals and humans, even if sometimes there are instances of misinterpretation in our communication. Advocating for mammals is further supported by the zoo institution's strategy in appealing to people: the majority of zoo logos and their websites feature pandas, orangutans, lions, giraffes, elephants and other species that catch people's attention and elicit a strong emotional response from the public (Cushing, Markwell 2011). Especially prevalent are pictures of newborn mammals, which speak in favour of the Lorenzian concept of Kindchenschema, and displaying these is a general tactic in raising visitor numbers during calving periods. ${ }^{9}$

\footnotetext{
A typical zoo concept meant to describe the likeability or attractiveness of an animal (e.g. Mullan, Marvin 1987: 74).

8 For example, most 20th-century conservation programmes were centred on large mammals (Adams 2004).

9 The Association of Zoos and Aquaria even has a webpage 'Zooborns' for exhibiting newborn animals, with a catchy slogan, "from cute to conservation" (Zooborn homepage. Avaible at: http://www.zooborns.com/; retrieved on 04.02.2015).
} 
Different species in zoos are, to a certain degree, managed in a way compatible with the visitors' perceptions of those species, due to the fact that the visitors' financial support is immensely important in order for the zoo's conservation endeavour to succeed (Hosey et al. 2009). This support can often be gained only together with moral support, indicating that people approve of the animal managing practices of the zoo. The greatest controversies regarding keeping wild animals in captivity and the ways they are kept are often arise in relation to charismatic mammals. The reason for this can lie in the fact that mammals have more complicated umwelts compared to, for example, invertebrate species. Thus, it is more difficult to create biologically suitable living conditions for them in the zoological garden, so these species are at the centre of attention and need to be dealt with in more depth. This claim holds ground to a certain point, but the other reason for mammals being at the centre of attention is their similarity to us. In other words, this means that the visitor's biological and cultural preferences for animals become a factor that zoos start taking into account when shaping their species collections and husbandry practices. Although welfare is a major concern in managing ex situ wildlife, paradoxically guaranteeing the animals' good welfare, including their species-specific behavioural characteristics, it is sometimes not in accordance with people's attitudes towards animals and their behaviour. The most evident cases are the predator-prey relationships, which are in many circumstances denied to large carnivorous mammals inhabiting zoological gardens (Mullan, Marvin 1987). Interestingly, when the prey is a small mammal (e.g. a mouse instead of a goat), fish or some species or invertebrate there is considerably less, if any, objection from the public. This peculiar finding may again be supported by our perception of similarity between the prey animal and ourselves, and a more neutral or indifferent attitude towards animals that we seem to have less in common with. It might be easier to feel empathetic towards a large mammal than a small mammal - especially if the small mammal is culturally perceived as a pest - while our umwelt is even less shared with that of a fish or a worm, a snail, etc.

There is a variety of different strategies employed to generalize the attitudes that people may hold towards zoo animals. These attitudes include, but are not limited to, welfaristic, conservational, utilitarian, mechanistic, phobic and dominionistic attitudes. In addition, there are also intermediate attitudes of the aforementioned, and furthermore, people may hold different attitudes toward different species and animals, and a certain species or animal may receive different attitudes from different people. These attitudes are depicted in Fig. 1, which is an adaptation of Martinelli's (2010: 311) model of anthropocentric attitudes towards animals. 


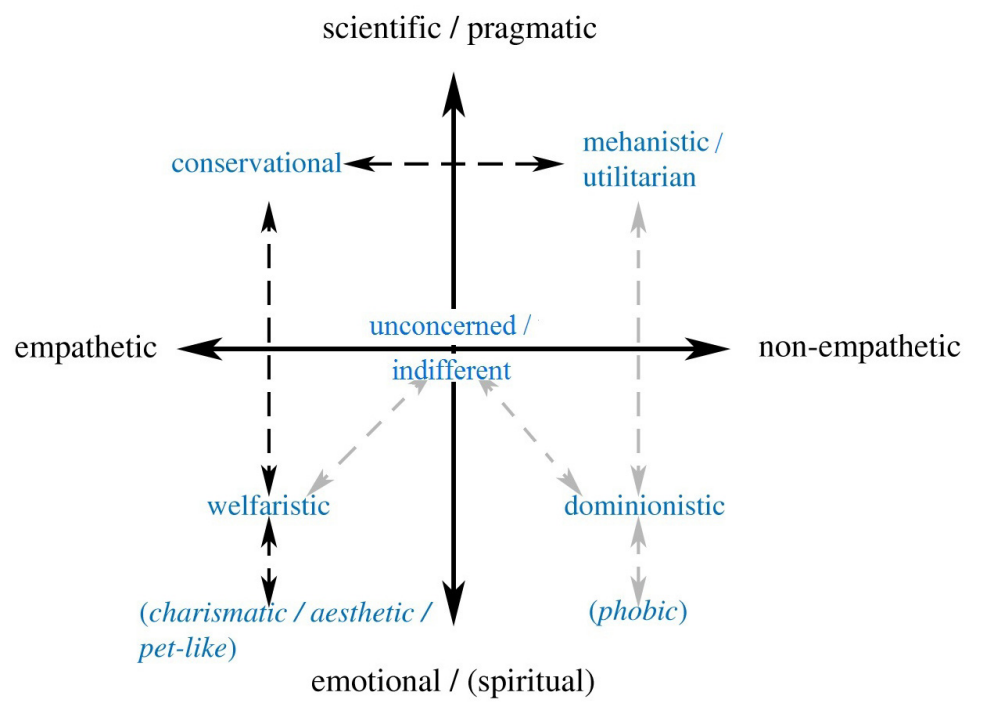

Figure 1. Dimensions of human attitudes towards animals.

The original model has been modified to describe the possible attitudes that different interest groups may hold towards animals in zoological gardens. In addition, it is used to portray the dynamics of shifting attitudes on the axis of empathetic/nonempathetic and scientific/pragmatic-emotional. Empathetic and non-empathetic can be considered as a general attitude of favouring or disregarding animals. ${ }^{10}$ The scientific/pragmatic and emotional axis represents whether the attitudes that people hold stem from emotions or if there is some accepted knowledge-based awareness. We shall discuss, in the light of proposed examples, the attitudes that fall on the general axes, i.e. the conservational, the mechanistic/utilitarian, the welfaristic, the dominionistic. We shall also discuss the relations between these attitudes and perceptions, where evident; these are marked with discontinuous black arrows. The movements that were not evident, but are theoretically possible, are drawn with discontinuous grey arrows. It must be stressed that although movement is possible on both axes (and most attitudes are not situated in extremes), the shift of attitudes between extremes - a diagonal movement on the model - cannot be done without intermediate steps, if at all.

Welfaristic perception can be observed in people who might have little knowledge of animal communication or the relations that animals have with their

\footnotetext{
10 The actual outcome of empathetic and non-empathetic attitudes does not necessarily always help or hurt animals.
} 
environment and conspecifics. Consequently, they may have beliefs that are not supported by ethological or other relevant studies. From their point of view, zoo animals are basically perceived as victims of human power and are considered weak and helpless, so people believe they have a moral duty to show compassion in aiding and supporting them. ${ }^{11}$ They want to see active and socialized animals living in nature-like conditions. Since we have shown that humans are species-biased, it is obvious that the welfaristic attitude does not apply equally to all species, or, as a matter of fact, to all individuals of the same species. People create connections on an emotional empathetic basis and it is much easier to connect to a single personified animal than to a general and abstract 'species'. Zoological gardens employ something that we call personification strategy, which means that individuals with whom the public can actually come into contact when visiting a zoo are given names, their life stories are displayed and their personal likes and dislikes are discussed during keeper talks, so that the welfaristic attitude could be channelled to an individual and intensified through the given narrative. In essence, pet-like perceptions of animals are encouraged; people are invited to create stronger positive attitudes towards these animals, similar to those with the pets they might have at home. However, in order to personify an animal, the animal has to be distinguishable from its conspecifics, which indicates that animals who are present in large numbers in zoological gardens are usually not separately identifiable for the public. So even though animal class plays a role in personification (mammals being once again favoured over others), the size and the rarity of the animal is also crucial. For example, marmosets usually have a dozen or more animals in one enclosure at a zoo, and although they have a quite high 'exhibition value' and are active, social and relatively compatible with the Kindchenschema notion, it is difficult for people to distinguish individual animals exhibited in such large numbers. Thus, it is uncommon for them to have public life stories and names. On the other hand, animals such as the American crocodile, who are neither 'warm and furry' nor particularly active and social compared to marmosets, but are large and exotic and often kept in small numbers, appear to be good candidates for personification. In the case of crocodiles, personification can also serve the purpose of decreasing phobic attitudes - herpetophobia being very common - or indifferent attitudes towards the animals.

To develop visitors' awareness of animals, zoological gardens appear to use a twostage strategy. Animal personification is used to raise a sentiment in people to make them care about the animal, so that public endorsement for species conservation could be achieved. In order to shift the attention based on emotions to the zoo's functions or goals, however, the zoo in turn needs to de-personify animals. They

11 They might not even know that welfare as a scientific stance, although advocating for the physical and mental well-being of an individual, does not oppose humane killing of an animal. 
need to show that although this particular animal will not suffer from hunger, habitat loss, or poachers, his or her conspecifics do, and they need people's support. The most common means to de-personify an animal, raising welfaristic attitudes towards the whole species, uses the same media as personification of the animal - through signage and keeper talks. At a zoo exhibit that a personified animal inhabits, there is a sign of the animal's life story, and next to it is a general description of the species and sometimes some comparison with species belonging to the same genus. Keeper talks and shows employ the same techniques - although they introduce the concrete animals and their personality traits, they mostly tend to move to more general topics of species behaviour or morphology and, of course, to conservational issues.

Such semiotic strategies combine individual and species-specific potentials of animals and may propagate welfaristic and conservational attitudes simultaneously. A conservational attitude projects people's perceptions of an animal to the whole species or population and welfaristic attitudes are directed toward concrete individuals. Although such a dyadic approach appears to be effective for the educational goals of the modern zoological gardens, there is also a downside that derives from the partial incompatibility of species conservation and animal welfare. Animals in conservation programmes are often treated as gene pools, meaning their mates for producing offspring are often selected on the basis of genetic diversity, while individual animals not contributing to this diversity are considered surplus and culled. ${ }^{12}$ This rational or scientific attitude towards animals can even be considered utilitarian on a pragmatic level, or dominionistic on an emotional level. Dominionistic perception is regarded as the opposite of welfaristic perception, and although they both emphasize human management of or control over animals, only in the case of dominionistic perception do people tend to feel non-empathetic towards the individual animals. It is possible for a person to have a welfaristic attitude towards an animal and also a conservational attitude towards the species that the animal belongs to, as long as there is no disruption between the two, especially if the life of the animal is under question. The culling of a personified animal with a name and a life-story is especially conflicting with the welfaristic perception of that animal. Thus, even though it is possible to change one's attitudes from welfaristic to conservational, the latter stance is more abstract and consequently more fragile. However, if a person has a prevalently conservational attitude towards a species, the perception of a member of that species can be more neutral or indifferent.

We apply a modified model of Martinelli's anthropocentric attitudes (Martinelli 2010: 311) to highlight the dynamics of conflicts in perceptions and attitudes that may arise in a concrete situation taking place in the zoo environment. This model serves to illustrate the possible movement between attitudes and perceptions and

12 If no other suitable zoological gardens are willing to take them. 
the possible conflicts arising in regard to different attitudes of different interest groups. We shall use only the relevant typologies of perceptions exemplifying the controversies appearing in our chosen case. The example is based on a giraffe - a large charismatic mammal - the tallest of all mammals that has a specific skin pattern of patches and a long neck as its distinctive features, making the giraffe one of the most popular species during a zoo visit. Although Lorenzian Kindchenschema may not apply to giraffes in the concept's traditional sense, the perceived awkwardness of the movements of giraffes (e.g. spreading their front legs to reach the ground) and the variety of their facial expressions (due to flexible mouth and long tongue), giraffes evoke strong emotional response and thus may be argued to possess the "cuteness factor". Once again, there are also cultural perceptions contributing to giraffes' popularity: "In the 21 st century, it has been named the national animal of Tanzania, and in Botswana it is considered to be 'royal' and may not be hunted. Its distinctive, iconic image is used across the world to advertise anything from mobile phones to insurance, motor bikes and whisky." ${ }^{13}$ Giraffes in situ can live and move in large herds or be solitary (mainly older males), in zoos they are grouped with regard to also economic and spatial restraints, which at times may prove to be difficult for their social relations (e.g. conflict-prone behaviour).

The case we are observing concerns Copenhagen zoo's giraffe who was shot, dissected in public and fed to the lions in early 2014. Although the giraffe was a charismatic mammal, he was not personified and thus did not have a pet-like representation of him during his life at the zoo. However, the attractive appearance and general cultural heritage gave the giraffe a potential to become an individualized subject of the discourse. His keepers had named him Marius ${ }^{14}$ and disclosed this information (along with his life story) to the media when the intentions of culling a perfectly healthy giraffe reached the public. Thus, the personified perception of him in the eyes of the public was formed on the verge of the giraffe's death and soon after it. People holding welfaristic attitudes strongly objected to the culling ${ }^{15}$ of Marius, especially since offers to take him were made by other zoos. ${ }^{16}$ Conservationists, on the other hand, stated that the giraffe's welfare had already been damaged, because he was too old to be in the herd he had been born in and his father was already abusing him. Sterilizing the animal would have damaged his quality of life. It has to

13 Giraffe Conservation Foundation 2013. Available at: http://www.giraffeconservation.org/ booklets.php (Retrieved on 10.10.2015).

14 See http://www.dr.dk/Nyheder/Indland/2014/02/10/131701.htm.

15 Welfaristic attitude holders called it 'butchering' and 'destroying' - revealing the act to bear strong negative connotations.

16 Thorton, Lucy 2014. Marius the giraffe butchered in front of children and fed to lions at Copenhagen Zoo. Mirror Online 10.02.2014. Available at: http://www.mirror.co.uk/news/ world-news/marius-giraffe-butchered-front-children-3129390 (Retrieved on 03.02.2015). 
be noted that Copenhagen zoo with its principle of not sterilizing animals creates a contrast with the majority of accredited zoos that do sterilize their animals, ${ }^{17}$ which indicates the importance of the cultural context in managing wildlife and has a direct influence on the animals' lives. Sterilized animals do not breed; on the other hand they miss out on social relations like rearing offspring. However having offspring creates the problem of managing them, especially in a spatially limited city zoo like that of Copenhagen. Since Marius' genes were well represented and there were no acceptable (accredited) zoos to give the animal to, Marius turned out to be simply surplus. ${ }^{18}$ It was also stated that the culling of the animal was conducted in a humane way out of sight of the public and he even had his last meal. ${ }^{19}$ In an act of providing the last supper and considering that the act of killing something should be done painlessly and not be shared by the public, conservationists had incorporated some of the welfaristic views into their own attitudes.

The welfaristic perception of Marius by the public was burdened by a lack of knowledge of demands for rehoming a zoo animal and the life quality of the animal. The welfarists could definitely not apprehend de-personifying Marius into a utilitarian view of "collection of genes useless to the breeding program" ${ }^{20}$ Before the culling, welfarists even gathered more than 27,000 signatures on a petition to save the giraffe's life. ${ }^{21}$ To worsen the controversy, mechanistic representations of the giraffe were also displayed - he was dissected like a research object in front of the public and later, parts of him were fed to lions. ${ }^{22}$ The welfarists answered with death threats to the zoo staff. ${ }^{23}$ According to media discourse study pertaining to this case, it also has to be brought to light that international mainstream media seems to constitute a higher relative amount of intensity and emotions than the Danish media scene (Zimmerman et al. 2014).

17 https://theconversation.com/death-of-marius-the-giraffe-reveals-cultural-differences-inanimal-conservation-23052

18 Copenhagen Zoo website. Available at: http://zoo.dk/BesogZoo/Nyhedsarkiv/2014/Februar/ Why\%20Copenhagen\%20Zoo\%20euthanized\%20a\%20giraffe.aspx (Retrieved on 04.02.2015).

19 See http://news.nationalgeographic.com/news/2014/02/140210-giraffe-copenhagen-science/.

20 Eriksen, Lars; Kennedy, Maev 2014. Marius the giraffe killed at Copenhagen zoo despite worldwide protests. The Guardian 09.02.2014. Available at: http://www.theguardian.com/ world/2014/feb/09/marius-giraffe-killed-copenhagen-zoo-protests (Retrieved on 04.02.2015). 21 Evans, Maria 2014. Save Marius the giraffe from the bolt gun NOW. Petition Site. Available at: http://www.thepetitionsite.com/528/607/193/save-marius-the-giraffe-from-the-bolt-gunnow/ (Retrieved on 04.02.2015).

${ }^{22}$ See http://www.theguardian.com/world/2014/feb/09/marius-giraffe-killed-copenhagenzoo-protests.

23 Smith, Roff 2014. Giraffe killing at Copenhagen Zoo sparks global outrage. National Geographic 10.02.2014. Available at: http://news.nationalgeographic.com/news/2014/02/ 140210-giraffe-copenhagen-science/ (Retrieved on 04.02.2015). 
In the context of the present article, it needs to be noted that the disagreement was in several ways related to the biological and cultural causes of human attitudes towards other animals. Being a charismatic mammal, the giraffe had semiotic potential for becoming a subject of personified perceptions and welfaristic attitudes. At the same time, public attachment to the charismatic mammals is a reason why zoological gardens are tempted to keep the giraffes, lions, zebras, bears and other charismatic mammals to appeal to people and raise visitor numbers. At least indirectly, the attractiveness of the large mammals to the public, in combination with different business and conservation aims of zoological gardens, creates the stage for the Marius controversy. The conflict of the welfaristic and utilitarian attitudes can be interpreted as a part of this larger social communicative system. We could not find any expressions of unconcerned/indifferent attitudes which is either due to the fact that most of the questions proposed for valuating a species received a positive answer or, redundantly, that people with indifferent attitudes remained unconcerned and thus do not speak out.

The example of the giraffe Marius also shows that it is not possible to reconcile the most personified perception (pet-like, welfaristic) with the extreme case of depersonification (utilitarian, mechanistic). However, in more moderate cases, there is the possibility, in essence, to shift one's perceptions and attitudes between neutralwelfaristic (empathetic personification ${ }^{24}$ ), welfaristic-conservational (empathetic depersonification) and even conservational-utilitarian/mechanistic (non-empathetic extreme de-personification). In these ways the personification/de-personification strategies described above are often used. It is also clear that different interest groups (e.g. visitors, animal rights activists, conservational biologists) may hold different perceptions of different animals or species. Moreover, the possible shifts or conflicts between different perceptions could be dependent on the type and management of the specific zoo, the local cultural context, the specific animal species under observation and other characteristics. The different perspectives are more obscure than they are straightforwardly coherent, and are brought forward to show the spectrum of general possibilities of how animals can be perceived. Therefore we suggest using the dimensions of welfaristic, conservational, dominionistic and utilitarian as a model for analysing specific communicative interactions and transitions in zoological gardens, and not as general categories of stakeholder perceptions. However, the proposed model can also be applied in analysing zoological gardens' self-representation, in order to guide their future endeavours. In mapping the causes for a specific communicative situation or conflict, a variety of factors need to be studied, including interests and cognitive dispositions of the stakeholders, cultural connotations and umwelt structure of the involved animal species, institutional goals of the specific zoological garden, etc.

24 Also a phobic-neutral shift in perception can use the same tactic. 


\section{Conclusions}

In the discourses of animal welfare studies, conservation biology and species management, species neutrality is often assumed or propagated as a general principle. We have demonstrated from a semiotic viewpoint that although a desirable principle, species neutrality almost never exists in actuality. People's attitudes towards animal species depend on, in addition to psychological dispositions of the people themselves, biosemiotic conditions (umwelt stucture, biocommunication) and cultural connotations/symbolic meanings. In real-life environments such as zoological gardens, both biosemiotic and cultural aspects influence which animals are displayed, as well as the various ways in which they are displayed. These dispositions are further used as motifs in staging, personifying or de-personifying animals in order to modify visitors' perceptions and attitudes in the direction favoured by the zoo, if those perceptions are not extremely contradictory. The communicative encounters and shifting perceptions can be analysed on the scales of welfaristic, conservational, dominionistic, and utilitarian approaches, which have different exposure to culturaland biosemiotic characteristics of animal species. The methodological approach described in this article integrates the static and dynamical approach by proposing to analyse semiotic potential of animals and dynamics of communicative interactions in combination. $^{25}$

\section{References}

Adams, William M. 2004. Against Extinction: The Story of Conservation. London: Earthscan. Batt, Sarah 2009. Human attitudes towards animals in relation to species similarity to humans:

A multivariate approach. Bioscience Horizons 2(2): 180-190.

Beever, Jonathan 2012. Meaning matters: The biosemiotic basis of bioethics. Biosemiotics 5(2): 181-191.

Bjerke, Tore; Østdahl, Torbjørn 2004. Animal-related attitudes and activities in an urban population. Anthrozoos: A Multidisciplinary Journal of The Interactions of People \& Animals 17(2): 109-129.

Conway, William 2003. The role of zoos in the 21st century. International Zoo Yearbook 38: 7-13.

Cushing, Nancy; Markwell, Kevin 2011. I can't look: Disgust as a factor in the zoo experience. In: Frost, Warwick (ed.), Zoos and Tourism: Conservation, Education, Entertainment? (Aspects of Tourism 46.) Bristol: Channel View Publications, 167-178.

Garibaldi, Ann; Turner, Nancy 2004. Cultural keystone species: Implications for ecological conservation and restoration. Ecology and Society 9(3), sine pagina.

25 Acknowledgements: The research for this article was supported by the European Union through the European Regional Development Fund (Centre of Excellence for Cultural Theory), as well as under institutional research grant IUT02-44 from the Estonian Research Council and under project contract EMP151 by the Norway Financial Mechanism 2009-2014. 
Hediger, Heini 1969. Man and Animal in the Zoo: Zoo Biology. New York: Delacorte Press.

Hills, Adelma M. 1993. The motivational bases of attitudes toward animals. Society \& Animals 1(2): 111-128.

Hoffmeyer, Jesper 2008. Biosemiotics: An Examination into the Signs of Life and the Life of Signs. Scranton: University of Scranton Press.

Hosey, Geoffrey; Melfi, Vicky; Pankhurst, Sheila 2009. Zoo Animals: Behaviour, Management, and Welfare. New York: Oxford University Press.

Kellert, Stephen R. 1985. Social and perceptual factors in endangered species management. The Journal of Wildlife Management 49(2): 528-536.

- 1988. Social and perceptual factors in the preservation of animal species. In: Norton, Bryan G. (ed.), The Preservation of Species. The Value of Biological Diversity. Princeton: Princeton University Press, 50-73.

Koontz, Fred 1995. Wild animal acquisition ethics for zoo biologists. In: Norton, Bryan G.; Maple, Terry; Stevens, Elizabeth (eds.), Ethics on the Ark: Zoos, Animal Welfare, and Wildlife Conservation. Washington, London: Smithsonian Institution Press, 127-146.

Kull, Kalevi 2001. Biosemiotics and the problem of intrinsic value of nature. Sign Systems Studies 29(1): 353-365.

Lacy, Robert 1995. Culling surplus animals for population management. In: Norton, Bryan; Maple, Terry; Stevens, Elizabeth (eds.), Ethics on the Ark: Zoos, Animal Welfare, and Wildlife Conservation. Washington, London: Smithsonian Institution Press, 187-194.

Lorenz, Konrad 1937. The companion in the bird's world. The Auk 54(3): 245-273.

- 1943. Die angeborenen Formen möglicher Erfahrung. Zeitschrift für Tierpsychologie 5(2): 235-409.

Mäger, Mart 1994. Linnud rahva keeles ja meeles [Birds in Folk Lore and Language]. (2nd ed.) Tallinn: Koolibri.

Maran, Timo 2015. Emergence of the "howling foxes": A semiotic analysis of initial interpretations of the golden jackal (Canis aureus) in Estonia. Biosemiotics 8(3): 463-482.

Maran, Timo; Martinelli, Dario; Turovski, Aleksei (eds.), 2011. Readings in Zoosemiotics. (Semiotics, Communication and Cognition 8.) Berlin: DeGruyter Mouton.

Markoš, Anton; Grygar, Filip; Hajnal, László; Kleisner, Karel; Kratochvíl, Zdeněk; Neubauer, Zdeněk 2009. Life as Its Own Designer: Darwin's Origin and Western Thought, (Biosemiotics 4). Springer: Dordrecht.

Martinelli, Dario 2007. Zoosemiotics: Proposal for a Handbook. (Acta Semiotica Fennica 26). Imatra: International Semiotics Institute at Imatra.

- 2008. Anthropocentrism as a social phenomenon: Semiotic and ethical implications. Social Semiotics 18(1): 79-99.

- 2010. A Critical Companion to Zoosemiotics: People, Paths, Ideas. (Biosemiotics 5.) Berlin, New York: Springer.

Moss, Andrew; Esson, Maggie 2010. Visitor interest in zoo animals and the implications for collection planning and zoo education programmes. Zoo Biology 29(6): 715-731.

Moss, Stephen 2004. A Bird in the Bush: A Social History of Birdwatching. London: Arum Press. Mullan, Bob; Marvin, Garry 1987. Zoo Culture. Illinois: University of Illinois Press.

Myers, Olin E.; Saunders, Carol D. 2004. Emotional dimensions of watching zoo animals: An experience sampling study building on insights from psychology. Curator: The Museum Journal 47(3): 299-321. 
Pahin, Phillip; Macfadyen, Alyx 2013. A human-animal relational aesthetic: Towards a zoophilic representation of animals in art. Biosemiotics 6(2): 231-243.

Portmann, Adolf 1964. New Paths in Biology. New York: Harper \& Row.

- 1990. Essays in Philosophical Zoology by Adolf Portmann. The Living Form and Seeing Eye. (Carter, Richard B., trans.) Lewiston: Edwin Mellen.

Randall, Alan 1986. Human preference, economics, and the preservation of species. In: Norton, Bryan G. (ed.), The Preservation of Species. The Value of Biological Diversity. Princeton: Princeton University Press, 79-109.

Rolston, Holmes III 1990. Property-rights and endangered species. University of Colorado Law Review 61(2): 283-306.

Schlegel, Jürg; Rupf, Reto 2010. Attitudes towards potential animal flagship species in nature conservation: A survey among students of different educational institutions. Journal for Nature Conservation 18(4): 278-290.

Serpell, James A. 2004. Factors influencing human attitudes to animals and their welfare. Animal Welfare 13(1): 145-151.

Uexküll, Jakob v. 1982. The theory of meaning. Semiotica 42(1): 25-82.

Woods, Barbara 2000. Beauty and the beast: Preferences for animals in Australia. Journal of Tourism Studies 11(2): 25-35.

Zimmerman, Chris; Chen, Yuran; Hardt, Daniel; Vatrapu, Ravi 2014. Marius, the giraffe: A comparative informatics case study of linguistic features of the social media discourse. Proceeding CABS '14 Proceedings of the 5th ACM International Conference on Collaoration Across Boundaries: Culture, Distance \& Technology, 131-140.

\section{Семиотические измерения отношения людей к другим животным (на примере зоопарка)}

В статье рассматриваются культурные и биосемиотические основы отношения людей к другим видам. Относясь критически к видовой нейтральности (species neutrality), автор показывает, что отношение человека к разным видам животных зависит от психологических предпосылок, биосемиотических условий (например, структуры умвельта), культурных коннотаций и символических значений. В условиях реальной жизни, например, в зоопарке, биосемиотические и культурные аспекты влияют на выбор экспонируемых животных и на то, как их репрезентируют и интерпретируют. Эти семиотические предпосылки используются как мотивы в постановке, персонифицируя или деперсонифицируя животных, с целью изменить восприятие и отношение посетителей зоопарка. В качестве примера анализируются противоречивые интерпретации умерщвления жирафа в зоопарке Копенгагена. Коммуникативные соприкосновения и меняющиеся перцепции отражаются на шкалах благосостояния, охраны природы, доминирования и утилитарности. Применямый методологический подход соединяет статические и динамические точки зрения, предлагая совместный анализ семиотического потенциала животных и динамики коммуникативных интеракций. 


\section{Semiootilised mõõtmed inimeste suhtumises teistese loomadesse: loomaaedade näide}

Artiklis analüüsitakse inimeste teistesse liikidesse suhtumise kultuurilisi ja biosemiootilisi aluseid. Võetakse kriitiline hoiak liigineutraalsuse suhtes ja näidatakse, et inimese suhtumine erinevatesse loomaliikidesse sõltub psühholoogilistest eeldustest, biosemiootilistest tingimustest (nt omailma struktuuridest), kultuurilistest konnotatsioonidest ja sümboolsetest tähendustest. Tegelikes keskkondades, nt loomaaedades mõjutavad nii biosemiootilised kui kultuurilised aspektid seda, milliseid loomi väljapanekusse valitakse ning kuidas neid esitatakse ning interpreteeritakse. Neid semiootilisi eeldusi kasutatakse kui motiive, et loomi lavastada, isikustada ning depersonifitseerida ning külastajate taju ning suhtumist muuta. Juhtumianalüüsina vaadeldakse Kopenhaageni loomaaia kaelkirjaku prakeerimisele antud vastandlikke tõlgendusi. Kommunikatiivsed kokkupuuted ning nihkuvad tajud paigutatakse heaolu, looduskaitse, domineerimise ning utilitaarse lähenemise skaalale. Artiklis kirjeldatav metodoloogiline lähenemine ühendab staatilised ja dünaamilised vaatenurgad, pakkudes välja loomade semiootilise potentsiaali ning kommunikatiivsete interaktsioonide dünaamika ühisanalüüsi. 